\title{
Changes in the Treatment of Primary Esophageal Motility Disorders Imposed by the New Classification for Esophageal Motility Disorders on High Resolution Manometry (Chicago Classification 4.0)
}

\author{
Fernando A. M. Herbella (D) - Leonardo M. Del Grande •
}

Francisco Schlottmann · Marco G. Patti

Received: February 22, 2021 / Accepted: March 16, 2021 / Published online: March 27, 2021

(C) The Author(s) 2021

\section{ABSTRACT}

The Chicago Classification is the most used classification for primary esophageal motility disorders (PEMD). This classification was recently updated to the 4.0 version. This opinion piece focuses on the possible implications for the treatment of PMED determined by the new classification. Chicago Classification 4.0 included two new concepts for the diagnosis of achalasia: (1) type III achalasia diagnosis demands $100 \%$ absent peristalsis defined as either failed peristalsis or spasm; (2) "inconclusive diagnosis of achalasia" was added as a possibility. Both may decrease unnecessary treatment. Esophagogastric junction outflow obstruction, distal esophageal spasm, and hypercontractile esophagus were only considered clinically significant when correlated to supportive testing and relevant clinical symptoms and in the absence of gastroesophageal reflux disease. This may decrease the surge of treatment, especially peroral endoscopic myotomy, based solely on manometric diagnosis.

F. A. M. Herbella $(\bowtie)$. L. M. Del Grande .

F. Schlottmann - M. G. Patti

Department of Surgery, Escola Paulista de Medicina, Federal University of Sao Paulo, Rua Diogo de Faria 1087 cj 301, Sao Paulo, SP 04037-003, Brazil

e-mail: herbella.dcir@epm.br
Keywords: Achalasia; Chicago classification; Esophageal manometry; Esophageal motility disorders; High-resolution manometry; Peroral endoscopic myotomy

\section{Key Summary Points}

Chicago 4.0 is the new classification for esophageal motility disorders based on high-resolution manometry.

Previous classification may have caused overtreatment of specific manometric patterns.

Chicago 4.0 defined criteria for clinically relevant specific manometric patterns.

\section{DIGITAL FEATURES}

This article is published with digital features, including a summary slide, to facilitate understanding of the article. To view digital features for this article, go to https://doi.org/10.6084/ m9.figshare.14217698. 


\section{INTRODUCTION}

The first widely accepted classification for esophageal motility disorders based solely on esophageal manometry was compiled by Richter in 2001 [1]. High-resolution manometry (HRM) was not available at that time but, certainly, the most relevant studies on primary esophageal motility disorders (PEMD) were conducted based on this classification. High-resolution manometry (HRM) made motility testing much more agreeable to patients (quicker test and no need to move the catheter once in place) and physicians (more intuitive, quicker learning) [2] but it was fundamentally a gift for researchers. First, all knowledge acquired by conventional manometry could be replicated under HRM. Second, HRM plots were so agreeable to the eyes that researchers started to see things that were probably in the conventional manometry tracings but were not perceived [3]. Every change in color, every inflection, every point was considered a new manometric parameter and many terms and parameters soon populated the literature.

The Chicago classification was designed by (and owes its name to) two gastroenterologists at Northwestern University in Chicago (John Pandolfino and Peter Kahrilas) who were pioneers in the development of HRM. They tried to standardize the interpretation of HRM but a widely accepted consensus was only obtained for the 3.0 version when significant simplification was adopted [4]. This classification was recently updated to the 4.0 version [5] with remarkable changes in many concepts [6], which may alter the way PEMD are treated.

This commentary focuses on the possible implications for the treatment of PMED determined by the new classification for esophageal motility disorders on high-resolution manometry (Chicago Classification 4.0).

\section{ACHALASIA}

Achalasia is still defined by aperistalsis of the esophageal body and a failure of the relaxation of the lower esophageal sphincter (LES) in response to swallowing (measured by the integrated relaxation pressure, IRP) (Fig. 1). Esophageal body pressurization after swallows defined types from I to III. Chicago Classification 4.0, however, included two new concepts for the diagnosis of achalasia: (1) type III achalasia diagnosis requires $100 \%$ absent peristalsis defined as either failed peristalsis or spasm; (2) "inconclusive diagnosis of achalasia" was added as a possibility.

The new classification clarifies that cases with an elevated IRP, and intermittent peristalsis should be diagnosed as esophagogastric junction outflow obstruction (EGJOO). EGJOO treatment is more complex than achalasia, and it will be discussed later but this distinction between achalasia and EGJOO certainly will prevent unnecessary treatment [7]. Probably several cases have been diagnosed as achalasia when in fact they were not. For several authors, per oral endoscopic myotomy (POEM) is the preferred therapy for achalasia type III. Curiously, when some case series of POEM for achalasia are carefully reviewed, the rate of type III is incredibly high-up to $50 \%[8,9]$, even though type III is the rarest form and present in around $15 \%$ of the cases $[10,11]$. More curiously yet, the proportion of type III in Heller's myotomy for achalasia never reaches this high rate of type III [12]. It is not known whether the cases previously called "vigorous achalasia" at the time of conventional manometry represent Chicago type III achalasia since the definition was based on simultaneous waves of $>37 \mathrm{mmHg}$ amplitude [13] and thus some cases of type II would be included as well. Even with a more liberal definition, severe cases represented $10-40 \%$ of the total cases of achalasia [14]. Whether this high proportion of type III cases in POEM series is an overdiagnosis or referral bias is not known.

'Inconclusive diagnosis for achalasia' falls within three conditions according to Chicago 4.0: first, absent contractility with no appreciable peristalsis in the setting of IRP values at the upper limit of normal in two positions, with or without pan-esophageal pressurization in $20 \%$ or more swallows. Interestingly, no definition for "upper limit of normal" was provided, and "with or without" does not add to a decision process. Nevertheless, this inconclusion is based 


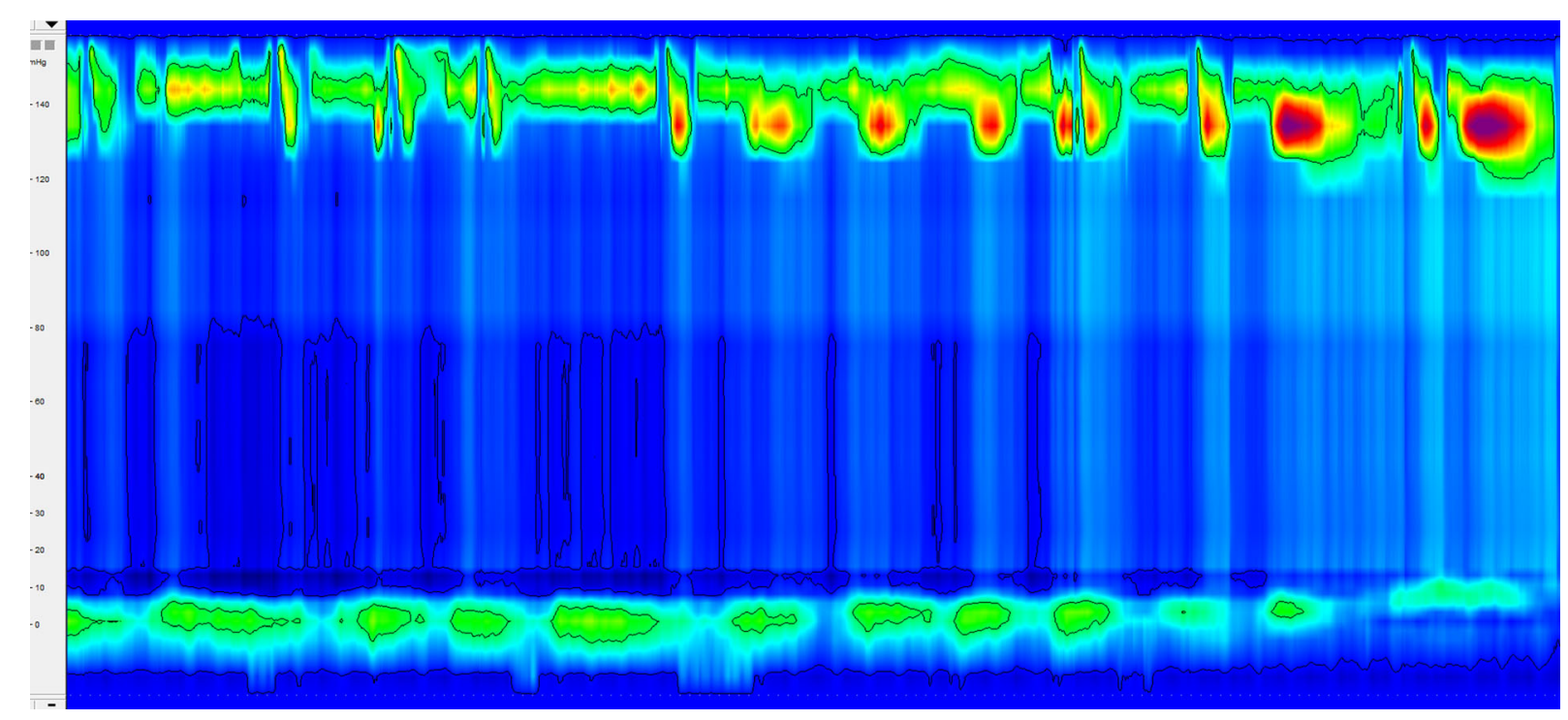

Fig. 1 Achalasia subtype I with no pressurization during swallows. The elevated integrated residual pressure (IRP) differentiates the case from absent contractility

on the lack of formal deficit in LES relaxation based on the IRP as a unique parameter. These cases have been previously studied. A normal IRP is not uncommon in untreated patients with achalasia. Vicentine et al. [15] showed that $57 \%$ of patients with Chagas' achalasia and $17 \%$ of patients with idiopathic achalasia had a normal IRP. Moreover, surgeons are used to treating patients after failed endoscopic therapy, making the evaluation of the LES faulty and relying only on the presence of aperistalsis at the HRM combined with other tests and clinical presentation [7]. If the diagnosis is based on a careful work-up and not based solely on manometry, outcomes are not jeopardized by the lack of a normal IRP [16]. Again, surgeons showed that Heller myotomy brings dysphagia relief even if the LES basal pressure is under the maximum normal IRP [17] or after endoscopic treatment at the LES resulting in apparent normal relaxation [18]. We compare the esophagogastric junction flow to a door. If the door is locked, closed, or ajar, one cannot pass through it. The door must be completely opened. For others, a 'normal' IRP may represent a door just ajar.

A second situation for 'inconclusive diagnosis for achalasia' is evidence of appreciable peristalsis with changing position in the setting of a type I or II achalasia pattern in the primary position. Interestingly, there is no recommendation to study patients with initial diagnosis of achalasia in two positions. We believe that this situation may occur if achalasia was NOT diagnosed in the initial position. Since supine is usually the standard position, we believe that a different diagnosis was based on the sitting or upright position. In this case, gravity may accelerate the transit, and a premature wave may be misinterpreted as aperistalsis by unexperienced examiners. Previous studies conducted by experts did not show a difference for the diagnosis of achalasia based on position $[19,20]$.

The third situation for 'inconclusive diagnosis for achalasia' is an inconclusive diagnosis of type III achalasia including an abnormal IRP with evidence of spasm and evidence of peristalsis. These patients should be classified as EGJOO with spastic features, which may represent an achalasia variant.

Other authors have proposed achalasia variants that were not supported by the Chicago 4.0 version, such as the variants in the Rochester classification [21]. It is valid to mention that South American experts frequently quote an 'indeterminate' variant of achalasia [15]. These experts have the chance to study patients with a 
positive serologic test for Chagas' disease in patients without esophageal symptoms to find a large spectrum of motility alterations [22]. Whether this represents early motility changes prior to complete aperistalsis or just occasional findings commonly found in asymptomatic individuals [23] is not known.

Supportive testing is recommended in the setting of these variants or inconclusive diagnosis, which is not different from what has been advocated previously [24].

\section{ESOPHAGOGASTRIC JUNCTION OUTFLOW OBSTRUCTION}

The Chicago 4.0 classification states that "a manometric diagnosis of EGJOO must always be considered clinically inconclusive." EJGOO should be considered clinically relevant only in the presence of: (1) an elevated IRP in supine and upright positions with evidence of peristalsis; (2) supportive investigations with other tests such as a barium swallow to document obstruction at the level of the gastroesophageal junction; (3) presence of chest pain and/or dysphagia (Fig. 2). This necessary update from version 3.0 including supportive testing and clinical correlation was fundamental to preventing overdiagnosis and unnecessary treatment since most individuals with a manometric picture of EJGOO are asymptomatic or have few symptoms which may often resolve spontaneously [25]. A surge in the indication of POEM for EJGOO was indeed seen after Chicago 3.0 [26-28]. These series apparently diagnosed EJGOO based mostly on manometric findings since supportive tests are not clearly mentioned and chest pain and/or dysphagia is not present in some patients. Surgeons, on the other hand, have been very cautious about surgical treatment for primary motility disorders apart from achalasia, particularly for functional obstructions at the level of the LES [29]. If we try again to correlate conventional manometry diagnosis with HRM, some cases of the previously named "hypertensive LES" could correspond to EJGOO. Patti et al. analyzed the results of the esophageal function tests in 3471 patients and diagnosed a primary esophageal motility disorder in 397

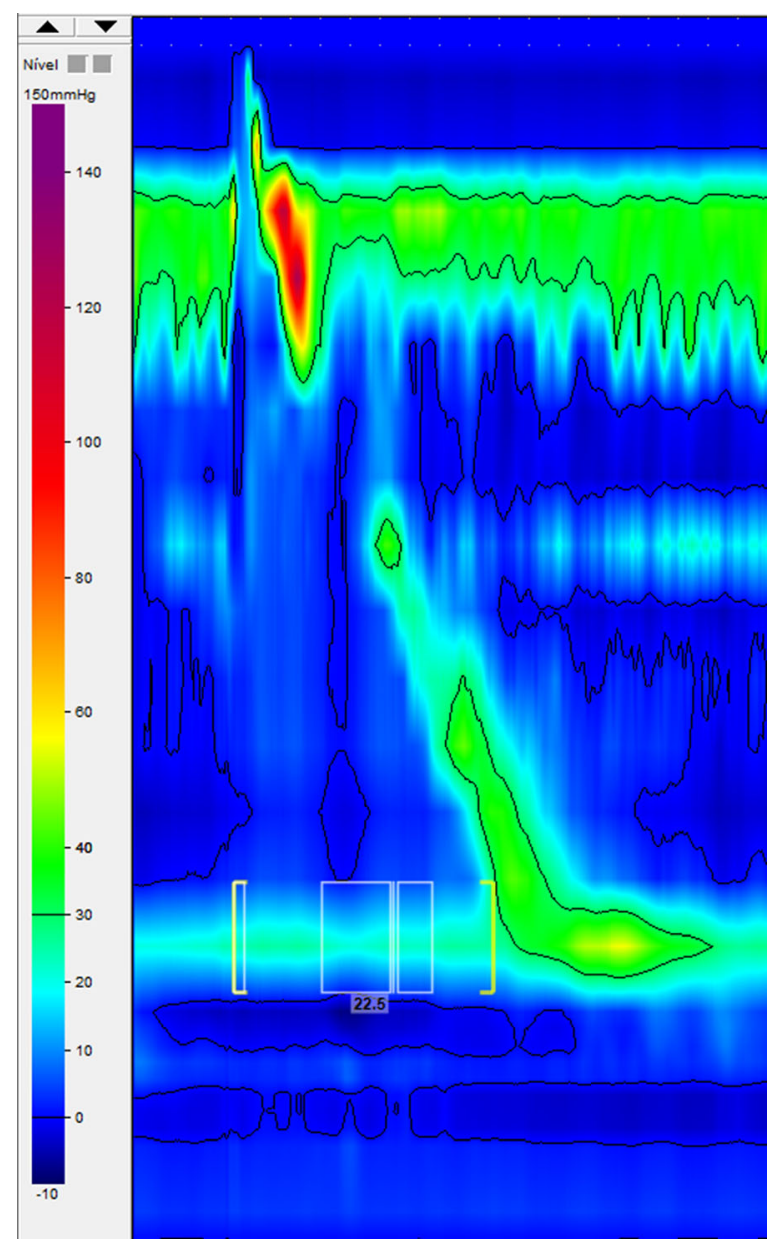

Fig. 2 Elevated integrated residual pressure (IRP) in a patient without dysphagia or chest pain and a normal esophagram. This case should not be classified as "esophagogastric junction outflow obstruction”

patients. Among these 397 patients only 2 had a hypertensive LES. After an extensive work-up, only one of the two patients underwent a myotomy with resolution of the symptoms [30]. In fact, we have showed that surgery for hypertensive LES should only be indicated in the presence of obstructive symptoms [31]. This shows that in the era prior to POEM when surgical therapy and endoscopic balloon dilatation of the cardia were the available forms of treatment, patients were extensively studied, carefully selected, and selectively treated. POEM as a new and attractive technology appears to lead to overtreatment as a consequence of the bright light of innovation [32]. In fact, the ethics of 
the adoption of POEM as the standard treatment for motility disorders has been the subject of some previous papers [33,33]. As a curiosity, Brazilian engineers take an oath saying that: "I swear that during my duty as Engineer I will not allow myself to be blinded by the bright light of technology, as I should not forget that I work for the benefit of humankind not for the benefit of the machine." Hippocrates did not anticipate this in the medical oath.

\section{DISTAL ESOPHAGEAL SPASM}

Distal esophageal spasm is still defined manometrically by at least $20 \%$ of premature contractions with normal contractile vigor; however, clinically relevant diagnosis of DES requires both clinically relevant symptoms (dysphagia and/or chest pain) and a conclusive manometric diagnosis. Similar to EJGOO, Chicago 4.0 incorporated clinical evaluation to avoid overtreatment. Also parallel to EJGOO, POEM has been extensively indicated as treatment [34-36] while operative treatment (Heller's myotomy) is parsimoniously used in very selected cases [37].

Another remarkable contribution of the Chicago 4.0 is to credit dysmotility to gastroesophageal reflux disease (GERD) (Fig. 3). PEMD must be only considered in the absence of GERD. This has been previously described [38] even though some authors, especially gastroenterologists, grouped the same manometric pattern in a single entity irrespective of the presence of GERD [39]. Moreover, the presence of the same manometric patterns found in PEMD does not affect outcomes for antireflux surgery [40].

Inconclusive diagnosis occurs with premature contractions and low contractile vigor as measured by the distal contractile integral (DCI) parameter. Conventional manometry classification [1] did not adopt waves amplitude for the diagnosis of diffuse esophageal spasm. Probably the contractile vigor is irrelevant for the diagnosis, which must be correlated to clinical complaints and supportive tests as described.

\section{HYPERCONTRACTILE ESOPHAGUS}

Hypercontractile esophagus is defined by excessive peristaltic vigor in at least 20 of the swallows. Jackhammer esophagus was considered a synonym in Chicago 3.0 but now jackhammer is considered a subset of the term hypercontractile esophagus only when repetitive prolonged contractions are present.

There are several contributions regarding hypercontractile esophagus. First, the fact that obstruction (either physiologic or mechanical) at the esophagogastric junction may lead to hypercontractile response was acknowledged. Thus, an obstruction must be ruled out before definitive diagnosis. Second, GERD must also be ruled out for the same reasons discussed at the distal spasm section. Third, similar to distal spasm, the pattern is clinically relevant in the presence of dysphagia and/or chest pain. Fourth, three different patterns were defined: single-peaked hypercontractile swallows, jackhammer, and hypercontractile swallows with a vigorous LES after-contraction (Fig. 4). These patterns still cannot be prognostic or tailor treatment because of the lack of studies mostly due to the rarity of the disease and recent definition.

Similar to other described PEMDs, POEM has been liberally used to treat hypercontractile esophagus [41] while surgery has been underused [37]. We showed that indications for surgery for nutcracker esophagus (probably most cases of nutcracker according to the conventional manometry classification correspond to hypercontractile esophagus) are the presence of obstructive symptoms and evidence of obstruction at the LES.

Finally, Chicago 4.0 tried to decrease overtreatment stating that "a cautious approach in terms of treating contractile vigor as an endpoint and advocated for conservative medical therapy before endoscopic or surgical interventions are considered." 


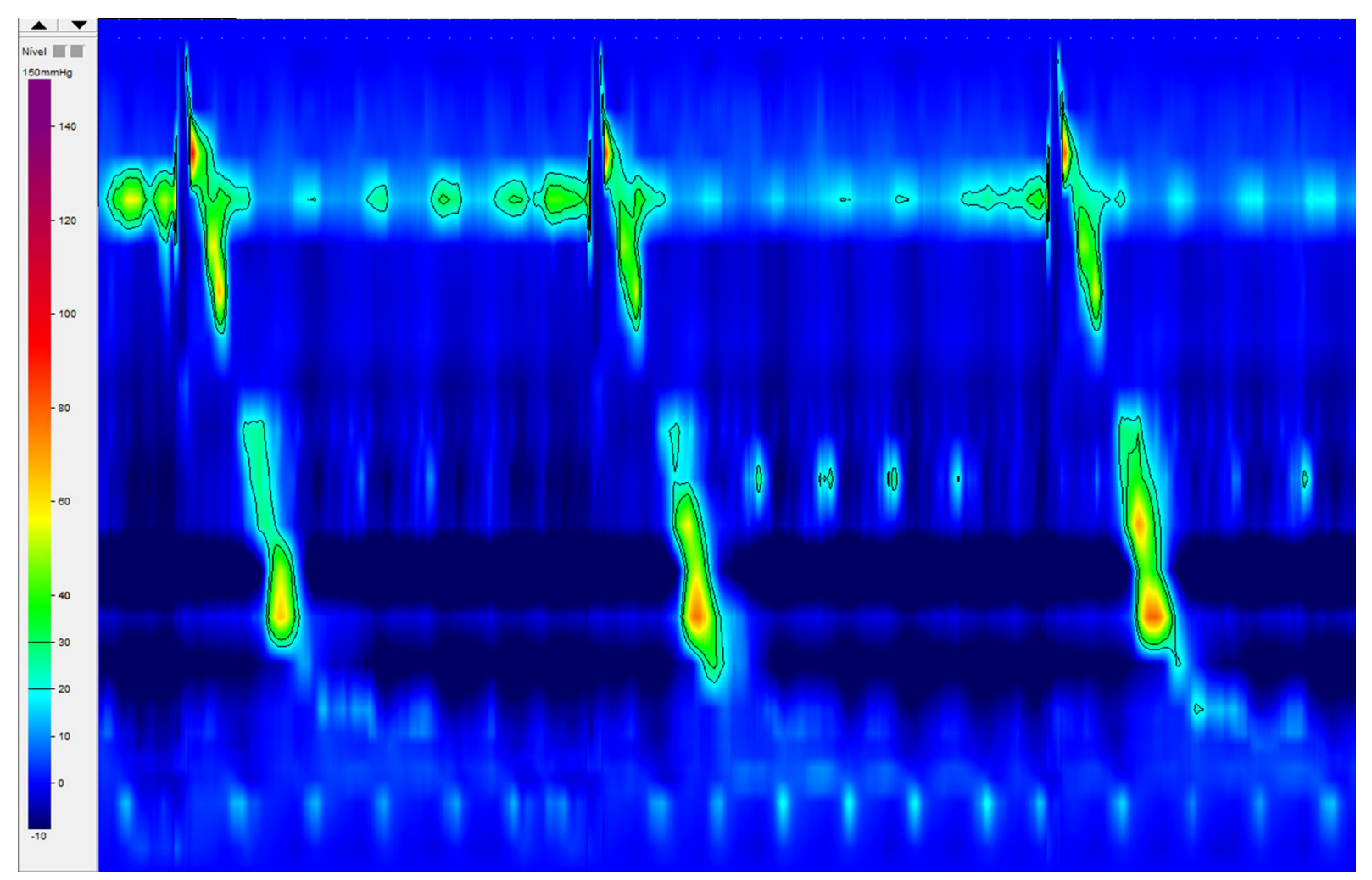

Fig. 3 Premature contractions in a patient with gastroesophageal reflux disease (note also the low basal pressure of the lower esophageal sphincter and an esophagogastric

\section{INEFFECTIVE ESOPHAGEAL MOTILITY AND ABSENT CONTRACTILITY}

The criteria for absent contractility were not updated in Chicago 4.0.

The definition of ineffective esophageal motility was updated in the Chicago 4.0. The diagnosis demands $>70 \%$ ineffective swallows (previously 50\%) or at least 50\% failed peristalsis (novelty) including fragmented peristalsis as ineffective swallow not as a distinct disease (novelty).

Absent contractility and ineffective esophageal motility as PEMD (GERD, medication usage, or systemic diseases should be excluded) have no specific treatment. No effective pharmacotherapy exists, and dietary intervention and lifestyle changes are the only available junction type II). Distal esophageal spasm is a primary esophageal motility disorders and can only be considered in the absence of other causes (i.e., gastroesophageal reflux)

resources [42]. We also refer patients to speech language pathologists to train forceful swallows even though there is still no scientific evidence behind the proposal, although a achalasia patients use this technique to pressurize the esophagus and facilitate esophageal clearance [43].

\section{CONCLUSIONS}

Chicago 4.0 has updated definitions that may correct overtreatment caused by previous classifications that considered specific manometric patterns as diseases based solely on manometric findings. The new classification defined clinically relevant diseases based on more discerning parameters that must be correlated to clinical symptoms and supportive testing besides the 


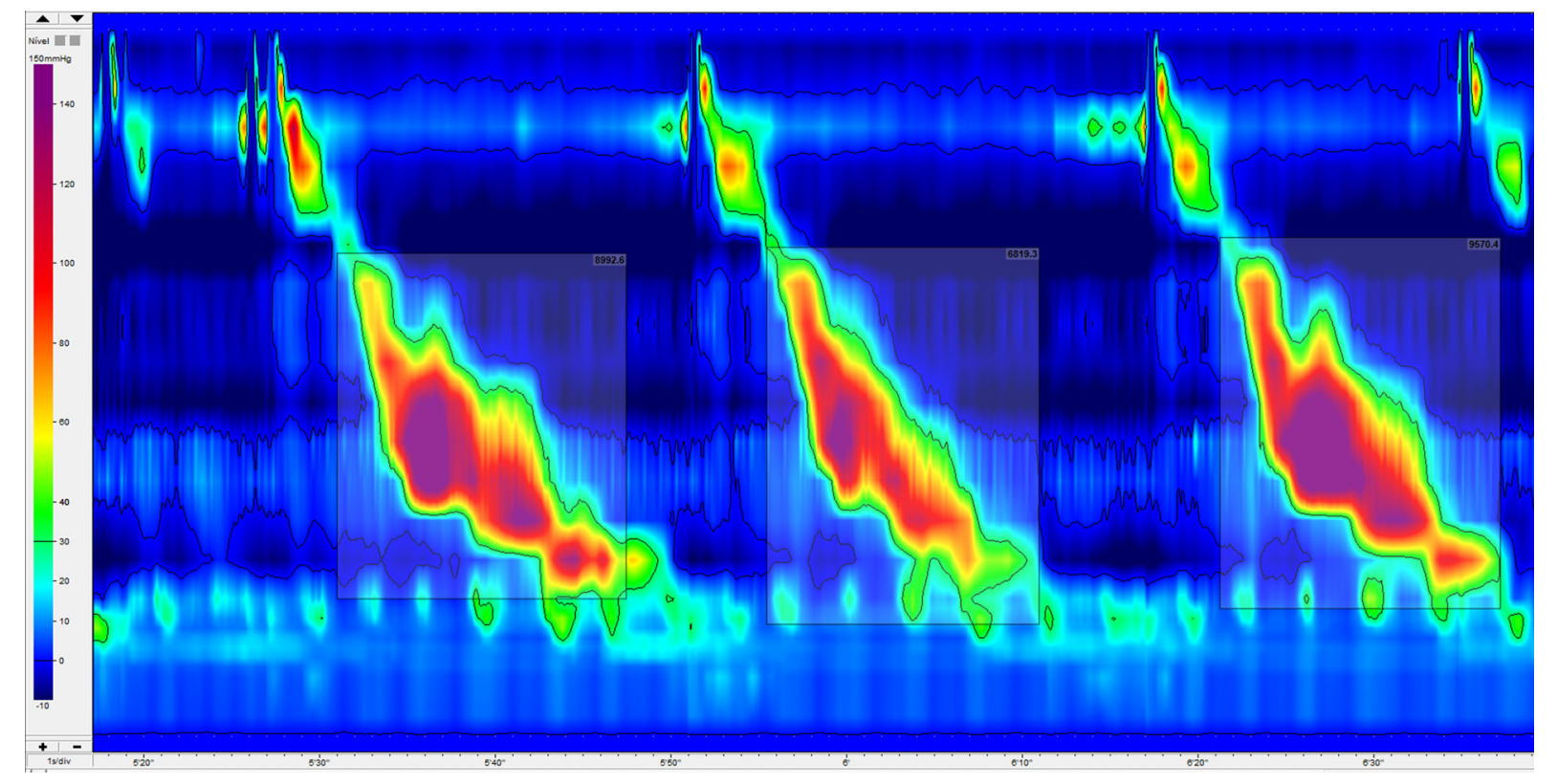

Fig. 4 Hypercontractile esophagus subtype single-peaked hypercontractile swallows. This form is no longer called jackhammer

exclusion of GERD that is logical to define an esophageal dysmotility as a primary disorder.

\section{ACKNOWLEDGEMENTS}

Funding. No funding or sponsorship was received for this study or publication of this article.

Authorship. All named authors meet the International Committee of Medical Journal Editors (ICMJE) criteria for authorship for this article, take responsibility for the integrity of the work as a whole, and have given their approval for this version to be published.

Authorship Contributions. The authors are responsible for the manuscript. No professional or ghost writer was hired.

FAMH: Conception and design, acquisition of data, drafting the article.

MGP: Conception and design, acquisition of data, drafting the article.

LMDG: acquisition of data, review for intellec- tual content, final approval of the version to be published.

FS: acquisition of data, review for intellectual content, final approval of the version to be published.

Disclosures. The authors Fernando A. M. Herbella, Leonardo M. Del Grande, Francisco Schlottmann and Marco G. Patti have nothing to disclose.

Compliance with Ethics Guidelines. This article is based on previously conducted studies and does not contain any new studies with human participants or animals performed by any of the authors.

Open Access. This article is licensed under a Creative Commons Attribution-NonCommercial 4.0 International License, which permits any non-commercial use, sharing, adaptation, distribution and reproduction in any medium or format, as long as you give appropriate credit to the original author(s) and the source, provide a link to the Creative Commons licence, and indicate if changes were made. The images or 
other third party material in this article are included in the article's Creative Commons licence, unless indicated otherwise in a credit line to the material. If material is not included in the article's Creative Commons licence and your intended use is not permitted by statutory regulation or exceeds the permitted use, you will need to obtain permission directly from the copyright holder. To view a copy of this licence, visit http://creativecommons.org/licenses/by$\mathrm{nc} / 4.0 /$.

\section{REFERENCES}

1. Richter JE. Oesophageal motility disorders. Lancet. 2001;358(9284):823-8. https://doi.org/10.1016/ S0140-6736(01)05973-6.

2. Salvador R, Dubecz A, Polomsky M, Gellerson O, Jones CE, Raymond DP, Watson TJ, Peters JH. A new era in esophageal diagnostics: the image-based paradigm of high-resolution manometry. J Am Coll Surg. 2009;208(6):1035-44. https://doi.org/10. 1016/j.jamcollsurg.2009.02.049.

3. Herbella FA, Patti MG. Can high resolution manometry parameters for achalasia be obtained by conventional manometry? World J Gastrointest Pathophysiol. 2015;6(3):58-61. https://doi.org/10. 4291/wjgp.v6.i3.58.

4. Kahrilas PJ, Bredenoord AJ, Fox M, Gyawali CP, Roman S, Smout AJ, Pandolfino JE, International High Resolution Manometry Working Group. The Chicago Classification of esophageal motility disorders, v3.0. Neurogastroenterol Motil. 2015;27(2): 160-74. https://doi.org/10.1111/nmo.12477 (Epub 2014 Dec 3. PMID: 25469569; PMCID: PMC4308501).

5. Yadlapati R, Kahrilas PJ, Fox MR, Bredenoord AJ, Prakash Gyawali C, Roman S, Babaei A, Mittal RK, Rommel N, Savarino E, Sifrim D, Smout A, Vaezi MF, Zerbib F, Akiyama J, Bhatia S, Bor S, Carlson DA, Chen JW, Cisternas D, Cock C, Coss-Adame E, de Bortoli N, Defilippi C, Fass R, Ghoshal UC, Gonlachanvit S, Hani A, Hebbard GS, Wook Jung K, Katz P, Katzka DA, Khan A, Kohn GP, Lazarescu A, Lengliner J, Mittal SK, Omari T, Park MI, Penagini R, Pohl D, Richter JE, Serra J, Sweis R, Tack J, Tatum $\mathrm{RP}$, Tutuian R, Vela MF, Wong RK, Wu JC, Xiao Y, Pandolfino JE. Esophageal motility disorders on high-resolution manometry: Chicago classification version 4.0@. Neurogastroenterol Motil. 2021;33(1):e14058. https://doi.org/10.1111/nmo. 14058 (PMID: 33373111).
6. Yadlapati R, Pandolfino JE, Fox MR, Bredenoord AJ, Kahrilas PJ. What is new in Chicago classification version 4.0? Neurogastroenterol Motil. 2021;33(1): e14053. https://doi.org/10.1111/nmo.14053 (Epub 2020 Dec 19. PMID: 33340190).

7. Herbella FAM, Patti MG. Chicago classification version $4.0 \odot$ from surgeons' point of view. Neurogastroenterol Motil. 2021. https://doi.org/10.1111/ nmo.14090 (Epub ahead of print. PMID: 33506552).

8. Kane ED, Budhraja V, Desilets DJ, Romanelli JR. Myotomy length informed by high-resolution esophageal manometry (HREM) results in improved per-oral endoscopic myotomy (POEM) outcomes for type III achalasia. Surg Endosc. 2019;33(3): 886-94. https://doi.org/10.1007/s00464-018-63560 (Epub 2018 Jul 27. PMID: 30054739).

9. Bernardot L, Roman S, Barret M, Vitton V, Wallenhorst T, Pioche M, Chaussade S, Gonzalez JM, Ponchon T, Prat F, Barthet M, Vergniol J, Chabrun E, Zerbib F. Efficacy of per-oral endoscopic myotomy for the treatment of non-achalasia esophageal motor disorders. Surg Endosc. 2020;34(12): 5508-15. https://doi.org/10.1007/s00464-01907348-y (Epub 2020 Jan 13. PMID: 31932930).

10. Roman S, Zerbib F, Quenehervé L, Clermidy H, Varannes SB, Mion F. The Chicago classification for achalasia in a French multicentric cohort. Dig Liver Dis. 2012;44(12):976-80. https://doi.org/10.1016/j. dld.2012.07.019 (Epub 2012 Aug 28. PMID: 22938702).

11. Rohof WO, Salvador R, Annese V, Bruley des Varannes S, Chaussade S, Costantini M, Elizalde JI, Gaudric M, Smout AJ, Tack J, Busch OR, Zaninotto $\mathrm{G}$, Boeckxstaens GE. Outcomes of treatment for achalasia depend on manometric subtype. Gastroenterology. 2013;144(4):718-25. https://doi.org/ 10.1053/j.gastro.2012.12.027 (quiz e13-e14, Epub 2012 Dec 28. PMID: 23277105).

12. Andolfi C, Fisichella PM. Meta-analysis of clinical outcome after treatment for achalasia based on manometric subtypes. Br J Surg. 2019;106(4): 332-41. https://doi.org/10.1002/bjs.11049 (Epub 2019 Jan 28. PMID: 30690706).

13. Camacho-Lobato L, Katz PO, Eveland J, Vela M, Castell DO. Vigorous achalasia: original description requires minor change. J Clin Gastroenterol. 2001;33(5):375-7. https://doi.org/10.1097/ 00004836-200111000-00006 (PMID: 1160685).

14. Herbella FA, Oliveira DR, Del Grande JC. Are idiopathic and Chagasic achalasia two different diseases? Dig Dis Sci. 2004;49(3):353-60. https://doi. org/10.1023/b:ddas.0000020486.71719.62 (PMID: 15139481). 
15. Vicentine FP, Herbella FA, Allaix ME, Silva LC, Patti MG. Comparison of idiopathic achalasia and Chagas' disease esophagopathy at the light of highresolution manometry. Dis Esophagus. 2014;27(2): 128-33. https://doi.org/10.1111/dote.12098 (Epub 2013 Jun 24. PMID: 23795824).

16. Sanagapalli S, Roman S, Hastier A, Leong RW, Patel K, Raeburn A, Banks M, Haidry R, Lovat L, Graham D, Sami SS, Sweis R. Achalasia diagnosed despite normal integrated relaxation pressure responds favorably to therapy. Neurogastroenterol Motil. 2019;31(6):e13586. https://doi.org/10.1111/nmo. 13586 (Epub 2019 Apr 7. PMID: 30957312).

17. Gorodner MV, Galvani C, Fisichella PM, Patti MG. Preoperative lower esophageal sphincter pressure has little influence on the outcome of laparoscopic Heller myotomy for achalasia. Surg Endosc. 2004;18(5):774-8. https://doi.org/10.1007/s00464003-8826-1 (Epub 2004 Apr 2. PMID: 15054655).

18. Bonavina L, Incarbone R, Antoniazzi L, Reitano M, Peracchia A. Previous endoscopic treatment does not affect complication rate and outcome of laparoscopic Heller myotomy and anterior fundoplication for oesophageal achalasia. Ital J Gastroenterol Hepatol. 1999;31(9):827-30 (PMID: 10669988).

19. Misselwitz B, Hollenstein M, Bütikofer S, Ang D, Heinrich H, Fox M. Prospective serial diagnostic study: the effects of position and provocative tests on the diagnosis of oesophageal motility disorders by high-resolution manometry. Aliment Pharmacol Ther. 2020;51(7):706-18. https://doi.org/10.1111/ apt.15658 (Epub 2020 Feb 13. PMID: 32056267).

20. Xiao Y, Nicodème F, Kahrilas PJ, Roman S, Lin Z, Pandolfino JE. Optimizing the swallow protocol of clinical high-resolution esophageal manometry studies. Neurogastroenterol Motil. 2012;24(10): e489-96. https://doi.org/10.1111/j.1365-2982. 2012.01989. (x Epub 2012 Aug 2. PMID: 22863083; PMCID: PMC3632389).

21. Galey KM, Wilshire CL, Niebisch S, Jones CE, Raymond DP, Litle VR, Watson TJ, Peters JH. Atypical variants of classic achalasia are common and currently under-recognized: a study of prevalence and clinical features. J Am Coll Surg. 2011;213(1): 155-61. https://doi.org/10.1016/j.jamcollsurg. 2011.02.008 (discussion 162-163. Epub 2011 Mar 23. PMID: 21435920).

22. Remes-Troche JM, Torres-Aguilera M, Antonio-Cruz KA, Vazquez-Jimenez G, De-La-Cruz-Patiño E. Esophageal motor disorders in subjects with incidentally discovered Chagas disease: a study using highresolution manometry and the Chicago classification. Dis Esophagus. 2014;27(6):524-9. https://doi. org/10.1111/j.1442-2050.2012.01438.x (Epub 2012 Oct 22. PMID: 23088758).

23. Rengarajan A, Rogers BD, Wong Z, Tolone S, Sifrim D, Serra J, Savarino E, Roman S, Remes-Troche JM, Ramos RI, Perez de la Serna J, Pauwels A, Leguizamo AM, Lee YY, Kawamura O, Hayat J, Hani A, Gonlachanvit S, Cisternas D, Carlson DA, Bor S, Bhatia S, Abrahao L, Pandolfino JE, Gyawali CP. High-resolution manometry thresholds and motor patterns among asymptomatic individuals. Clin Gastroenterol Hepatol. 2020. https://doi.org/10.1016/j.cgh. 2020.10.052 (Epub ahead of print. PMID: 33144149).

24. Zaninotto G, Bennett C, Boeckxstaens G, Costantini M, Ferguson MK, Pandolfino JE, Patti MG, Ribeiro U Jr, Richter J, Swanstrom L, Tack J, Triadafilopoulos G, Markar SR, Salvador R, Faccio L, Andreollo NA, Cecconello I, Costamagna G, da Rocha JRM, Hungness ES, Fisichella PM, Fuchs KH, Gockel I, Gurski R, Gyawali CP, Herbella FAM, Holloway RH, Hongo M, Jobe BA, Kahrilas PJ, Katzka DA, Dua KS, Liu D, Moonen A, Nasi A, Pasricha PJ, Penagini R, Perretta S, Sallum RAA, Sarnelli G, Savarino E, Schlottmann F, Sifrim D, Soper N, Tatum RP, Vaezi MF, van Herwaarden-Lindeboom M, Vanuytsel T, Vela MF, Watson DI, Zerbib F, Gittens S, Pontillo C, Vermigli S, Inama D, Low DE. The 2018 ISDE achalasia guidelines. Dis Esophagus. 2018. https://doi.org/10.1093/dote/doy071 (PMID: 30169645).

25. Samo S, Qayed E. Esophagogastric junction outflow obstruction: where are we now in diagnosis and management? World J Gastroenterol. 2019;28(25): 411-7.

26. Khashab MA, Familiari P, Draganov PV, Aridi HD, Cho JY, Ujiki M, Rio Tinto R, Louis H, Desai PN, Velanovich V, Albéniz E, Haji A, Marks J, Costamagna G, Devière J, Perbtani Y, Hedberg M, Estremera F, Martin Del Campo LA, Yang D, Bukhari M, Brewer O, Sanaei O, Fayad L, Agarwal A, Kumbhari V, Chen YI. Peroral endoscopic myotomy is effective and safe in non-achalasia esophageal motility disorders: an international multicenter study. Endosc Int Open. 2018;6(8):E1031-6. https://doi. org/10.1055/a-0625-6288 (Epub 2018 Aug 10. PMID: 30105290; PMCID: PMC6086680).

27. Ichkhanian Y, Sanaei O, Canakis A, Vosoughi K, Almazan E, Ghandour B, Khashab MA. Esophageal peroral endoscopic myotomy (POEM) for treatment of esophagogastric junction outflow obstruction: results from the first prospective trial. Endosc Int Open. 2020;8(9):E1137-43. https://doi.org/10. 1055/a-1198-4643 (Epub 2020 Aug 31. PMID: 32904698; PMCID: PMC7458721).

28. Jacobs CC, Perbtani Y, Yang D, Al-Haddad MA, Obaitan I, Othman M, Groth S, Sethi A, Agarunov 
E, Repici A, Maselli R, Galtieri A, Moremen J, Jenkins HN, Samarasena JB, Chang KJ, Draganov PV. Per-oral endoscopic myotomy for esophagogastric junction outflow obstruction: a multicenter pilot study. Clin Gastroenterol Hepatol. 2020;S1542-3565(20):31157-65. https://doi.org/10. 1016/j.cgh.2020.08.048 (Epub ahead of print. PMID: 32835840).

29. Herbella FA, Tineli AC, Wilson JL Jr, Del Grande JC. Surgical treatment of primary esopha-geal motility disorders. J Gastrointest Surg. 2008;12(3):604-8. https://doi.org/10.1007/s11605-007-0379-5 (Epub 2007 Nov 13. PMID: 17999124).

30. Patti MG, Gorodner MV, Galvani C, et al. Spectrum of esophageal motility disorders. Implications for diagnosis and treatment. Arch Surg. 2005;140: 442-9.

31. Herbella FA, Tineli AC, Wilson JL Jr, Del Grande JC. Surgical treatment of primary esophageal motility disorders. J Gastrointest Surg. 2008;12(3):604-8. https://doi.org/10.1007/s11605-007-0379-5 (Epub 2007 Nov 13. PMID: 17999124).

32. Patti MG, Schlottmann F, Herbella FA. The treatment of esophageal achalasia: at the intersection between innovation and patient's care. J Laparoendosc Adv Surg Tech A. 2020;30(3):233-5. https:// doi.org/10.1089/lap.2019.0718 (Epub 2020 Jan 2. PMID: 31895620).

33. Ferreres AR, Patti MG. Ethical issues in the introduction of new technologies: from Mis to POEM. World J Surg. 2015;39(7):1642-8. https://doi.org/ 10.1007/s00268-015-3067-8 (PMID: 25894402).

34. Estremera-Arévalo F, Albéniz E, Rullán M, Areste I, Iglesias R, Vila JJ. Efficacy of peroral endoscopic myotomy compared with other invasive treatment options for the different esophageal motor disorders. Rev Esp Enferm Dig. 2017;109(8):578-86. https://doi.org/10.17235/reed.2017.4773/2016 (PMID: 28617027).

35. Albers D, Frieling T, Dakkak D, Kuhlbusch-Zicklam R, Töx U, Gittinger M, Schumacher B. Peroral endoscopic myotomy (POEM) is effective in treatment of noncardiac chest pain caused by hypercontractile esophageal motility disorders: results of the POEM-HYPE-Study. Z Gastroenterol. 2018;56(11):1337-42. https://doi.org/10.1055/a0668-2605 (English. Epub 2018 Oct 8. PMID: 30296811).

36. Nabi Z, Chavan R, Ramchandani M, Basha J, Jagtap N, Karyampudi A, Darisetty S, Tandan M, Goud R, Rao GV, Reddy DN. Long-term outcomes of per-oral endoscopic myotomy in spastic esophageal motility disorders: a large, single-center study. J Clin Gastroenterol. 2020. https://doi.org/10.1097/MCG. 0000000000001395 (Epub ahead of print. PMID: 32657960).

37. Herbella FAM, Schlottmann F. Minimally invasive surgery for non-achalasia primary esophageal motility disorders is currently underused. Miniinvasive Surg. 2019;3:24. https://doi.org/10.20517/ 2574-1225.2019.20.

38. Herbella FA, Raz DJ, Nipomnick I, Patti MG. Primary versus secondary esophageal motility disorders: diagnosis and implications for treatment. J Laparoendosc Adv Surg Tech A. 2009;19(2):195-8. https://doi.org/10.1089/lap.2008.0317 (PMID: 19260789).

39. Almansa C, Heckman MG, DeVault KR, Bouras E, Achem SR. Esophageal spasm: demographic, clinical, radiographic, and manometric features in 108 patients. Dis Esophagus. 2012;25(3):214-21. https://doi.org/10.1111/j.1442-2050.2011.01258.x (Epub 2011 Sep 23. PMID: 21951821).

40. Dell'Acqua-Cassão B, Mardiros-Herbella FA, Farah JF, Bonadiman A, Silva LC, Patti MG. Outcomes of laparoscopic Nissen fundoplication in patients with manometric patterns of esophageal motility disorders. Am Surg. 2013;79(4):361-5 (PMID: 23574844).

41. Khan MA, Kumbhari V, Ngamruengphong S, Ismail A, Chen YI, Chavez YH, Bukhari M, Nollan R, Ismail MK, Onimaru M, Balassone V, Sharata A, Swanstrom L, Inoue H, Repici A, Khashab MA. Is POEM the answer for management of spastic esophageal disorders? A systematic review and meta-analysis. Dig Dis Sci. 2017;62(1):35-44. https://doi.org/10. 1007/s10620-016-4373-1 (Epub 2016 Nov 17. PMID: 27858325).

42. Gyawali CP, Sifrim D, Carlson DA, Hawn M, Katzka DA, Pandolfino JE, Penagini R, Roman S, Savarino E, Tatum R, Vaezi M, Clarke JO, Triadafilopoulos G. Ineffective esophageal motility: concepts, future directions, and conclusions from the Stanford 2018 symposium. Neurogastroenterol Motil. 2019;31(9): e13584. https://doi.org/10.1111/nmo.13584 (Epub 2019 Apr 11. PMID: 30974032).

43. Anefalos A, Herbella FAM, Patti MG. Upper esophageal sphincter motility and thoracic pressure are determinants of pressurized waves in achalasia subtypes according to the Chicago classification. World J Surg. 2020;44(6):1932-8. https://doi.org/ 10.1007/s00268-020-05396-3 (PMID: 32006132). 